\title{
Effects of Selected Soil and Water Conservation Structures on Soil Physiochemical Properties, Lemo Woreda, Southern Ethio- pia
}

\author{
Mulatu Chernet Madolo ${ }^{*}$. Yohannes Horamo More ${ }^{1}$ and Melese Gogo Masamo
}

\author{
Department of Natural Resource Management, Wachemo University, Hossana, Ethiopia P.O Box 667 \\ *Corresponding author: Mulatu Chernet \\ Department of Natural Resource Management \\ Wachemo University, Hossana, Ethiopia PO. Box 667 \\ * Correspondence: cmulachew@gmail.com, Mulatuchernet@wcu.edu.et
}

\begin{abstract}
Soil erosion is now almost universally recognized as a serious threat to man's well-being, if not his very existence. As a result, we assessed the soil physicochemical properties of two possible levels of soil bund and fanya juu. RCBD with three replications was used to collect soil samples from each soil conservation structure. Five composite soil samples were collected from each soil structure based on slop $(0-30 \mathrm{~cm})$. Soil physicochemical properties such as erosion index, dispersion ratio, and erodibility proportionality ratio were investigated. The effect of different soil structure levels revealed that soil properties differed significantly $(\mathrm{P} \leq 0.05)$ for all parameters studied. The control plots had significantly higher $(\mathrm{P} \leq 0.05)$ dispersion ratio, erosion indexes, and erodibility proportionality than the soils treated by the level bund and level Fanya juu structures. On the control plot, this result showed lower clay content and higher sand content. The level of soil bund and fanya juu had a significant $(\mathrm{P} \leq 0.05)$ effect on soil $\mathrm{OC}, \mathrm{CEC}, \mathrm{OM}$, and $\mathrm{TN}$, as well as available phosphorous and potassium. As a result, all related soil properties show a positive relative change when the level of soil bund and fanya juu is compared to the control plot. Aside from this result, the dynamic natures of the sciences compel us to conduct additional research based on the agro-ecological zones of the study area.
\end{abstract}

Keywords: Erodibility; Fanya juu; Soil bund; Soil physicochemical properties

\section{Introduction}

Today, soil erosion is almost recognized as a serious threat to man's well-being, if not to his very existence. Recent estimates indicates annual soil loss in Ethiopia is between 1.5 and 3 billion tons [1], of this about $50 \%$ occurs in cropland where soil loss has been reported to be very high (296 tons/ha/year) on a 16\% slope with "teff" crop (Eragrostis abyssinica) on nitisols [2] and [3]. The EHRS study estimated that about $50 \%$ of the high lands are already significantly eroded, of which about 14 million hectares are severely eroded. In Ethiopia, two millions hectares have reached a stage of irreversible destruction and cannot sustain cropping in the future [1].

The effects of soil degradation can be described as: flood hazard, decreases in productivity of the land as well as production per unit area, and the regulatory capacity of the mountains is drastically reduced and the overall effect is frequent drought, famine, and related disasters. Ethiopia has a long history of following traditional conservation methods [4] and [5]. These are numerous examples of certain parts of the country where these techniques can be seen. Stone terracing in Konso as well as Gomugoffa, for example, random bench terraces in North Shoa and Hararge, and contour bench terraces in Hararge and tied ridges in Konso, drainage furrows of North-East Shoa, and sod rotation, trash bunds, trash heap composting and fallowing. To date, these techniques have not been evaluated nor has there been any attempt to improve them or popularize them [3]. 
The scientific conservation programme is a recent phenomenon. A start was made in the early 1970s. However, serious attempts on a large scale were delayed until the early 1970s, when the assistance of the WFP and UNDP/FAO became available [6]. The Ethiopian high lands saw probably the most extensive soil conservation activity in the 1970s and 1980s [7] and [8]. Between 1980 and 1990, about 2.3 million ha of land was covered by hill side terraces in a forestation of the steep slopes; about 1 million hectares was planted with different tree seedlings [9].

One of these high land areas of Ethiopia is Hadiya zone, Lemmo district, where these soil conservation practices by government program were carried out. According to Department of Agricultural and Natural Resources Development report of Hadiya zone, $21,185.89$ hectares was covered by tree seedlings in one decade and 15,000 hectares was covered by soil conservation structures within five years [10]. Even if so much amount of land is covered by soil conservation structures, their effects brought by sustainable funding are not yet investigated. This is to mean no research was made to investigate the effects of these soil and water conservation structures on soil physicochemical properties. Hence, this research aimed at investigating the effects of specified soil and water conservation structures (level and fanya juu) bunds on the physicochemical properties of the soil.

\section{Material and methods}

Design of the Research

Seven experimental sites, each of them consists of three treatments, namely, level bund, control plot, and level fanya juu. They are also closer together to avoid external factors such as pest infestation, plant diseases, and other agro ecological factors. Graded bund and graded fanya juu are not selected because they are not available in the district.

Plot Layout

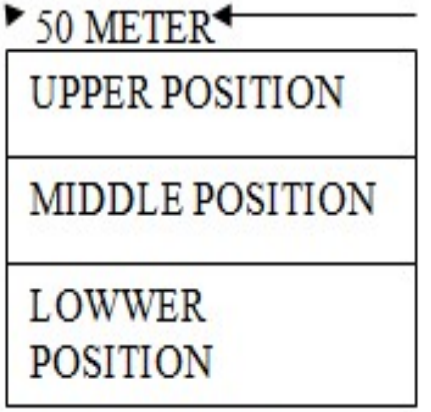

LEVEL BUND

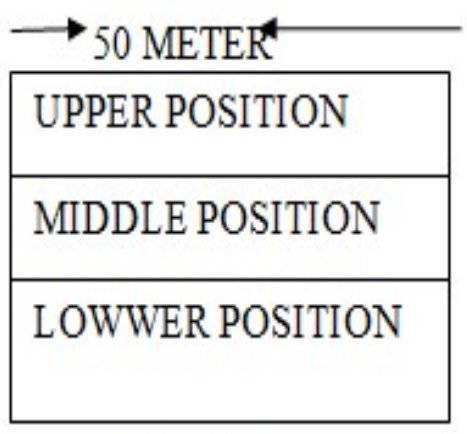

CONTROL

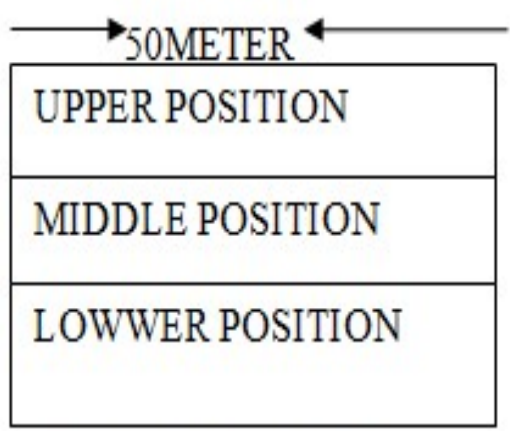

LEVEL FANYAJUU

The plot length and width are $15 \mathrm{~m}$ and $50 \mathrm{~m}$, respectively. The interstructural space was divided in to three positions of $5 \mathrm{~m}$ length.

\section{Description of the Study Area}

This study was conducted in Lemo District, Hadiya zone, Southern Ethiopia. Geographically, the study area is located in $07^{0} 41^{\prime} \mathrm{N}$ Latitude and $037^{\circ} 31^{\prime} E$ Longitude. Topography of the study area is rugged high land and hilly areas with a range of slope from 235 percent. Generally, the terrain is mountainous, undulating, and broken type that is very much prone to soil erosion. According to Gilmour (2016), land-use planning, soil types or the distribution of soil units in the study area is sand-sandy loam, loam, and clay. As it has been indicated above, the most widely distributed or that covers a large areas is loam. They are distinguished by a high amount of clay and these soils are high fertile and probably well-drained. 
The District is found in 'Woina Dega' agro-climatic zone with an altitudinal range of 1950-2400 meters above sea level. It has a temperature range of $15-18^{\circ} \mathrm{C}$ and an average rainfall is $1150 \mathrm{~mm}$. In the study area, there are a number of rivers and seasonal streams that drain to the area. They supply water for both drinking and sanitation purposes. The activities and intervention of human beings have influenced the natural vegetation in the study area greatly. Farmers are already adapted to the planting of some tree species in the district, to meet the demand for wood needs. This is actually dominated by different types of Eucalyptus species.

The District has a population of 207,469, of which 103,576 are male and 103,893 female. The dominant land-use types in the district are sedentary mixed farming, whereby the cultivated land accounts for $89 \%$ of the total land area. This in turn indicates that there is great pressure on land. The area practices complete integration of trees, crop, and animal production which is similar to the study of [11].
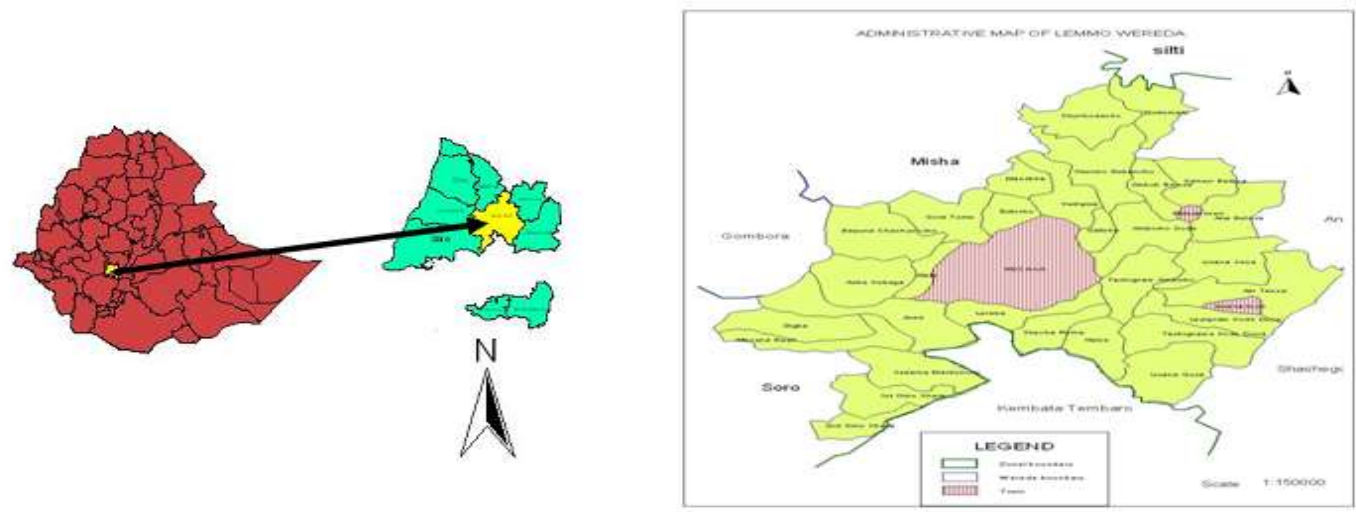

Figure 1. Location of Lemo District in Hadiya zone, Ethiopia (Source: Survey result).

\section{Sampling Techniques and Data Collection}

Composite auger hole sample (each made from subsamples collected from 3 different spots, upper, middle, and lower portion of the plot) were taken along the major slope to a depth of $0-30 \mathrm{~cm}$. A total of 63 composite samples, 42 for treated plots and 21 for untreated plots, were collected. For the determination of some parameters, such as bulk density, 63 undisturbed core soil samples, which retain the original pore geometry, were collected from each experimental plot. The soil parameters and methods of their analysis are given below. The undisturbed core soil samples and disturbed soil samples collected before planting were bagged separately with appropriate labels and transported to University Laboratory, and all disturbed soil samples were air dried by separating in canvas or trays and placing it on an open air for several days. The air-dried soil samples were grounded to pass through a two $\mathrm{mm}$ size sieve in preparation for laboratory analysis. Analyses were carried out on soil texture, bulk density $\left(\mathrm{gm} / \mathrm{cm}^{3}\right)$, Total pore space $(\%)$, water holding capacity (\%), Dispersion ratio, Erosion index, $\mathrm{pH}(1: 2.5)$, organic carbon (\%), total nitrogen (\%), Available potassium $(\mathrm{mg} / \mathrm{kg})$, Available phosphorus (\%) and CEC (meq/100gram).

The soil samples collected before planting the crop were analyzed for different physicochemical properties of the soil. Standard laboratory procedures were employed for the parameters required. In determining the particle size, the density of soil-water suspension was measured with a Bouyoucos hydrometer as described by [7]. Bulk densities were measured in an undisturbed condition by driving a cylindrical cutter carefully in to the soil, dug out, cleaned, trimmed, and weighed. Available Water holding capacity was determined by subtracting the soil water potential at the wilting point ( -15 bar) from that of the field capacity (-1/3bar) using a pressure plate apparatus [12]. Soil $\mathrm{pH}$ were measured 
potentiometrically in the supernatant suspension of a 1:1 or 1:2.5 soil: liquid mixture by using a $\mathrm{pH}$ meter. Total porosity was found using the moisture loss equation (1) [13].

$$
\begin{aligned}
& \text { Total porosity }(\%)= \\
& \frac{\text { wt. of sat. soil }- \text { wt. of ovendry soil }}{\text { volume of core } x \text { density of water }} \times 100
\end{aligned}
$$

Organic carbon was determined following the wet digestion method and oxidizable organic matter was also determined using the method described by [14]. The Kjeldahl procedure [15] was used to determine the total nitrogen based on the principle that treats the soil with concentrated sulfuric acid. [16] Solution was used to determine potassium in the soil. Two methods [17] were described for the determination of available phosphorus. The Olsen extraction method, which was used for acidic and nonacidic soils [18], was employed [19]. Erodibility was determined by [20] method using equation (2). Dispersion ratio was found out by using equation (3) as given by [21].

$$
\mathrm{EP}=\frac{\% \text { sand }+\% \text { silt }}{\% \text { clay }}
$$

Where: $\mathrm{EP}=$ erodibility proportionality, \% sand = percent sand found in the texture separation, \%silt = percent silt obtained in texture separation, and $\%$ clay = percent clay obtained in texture separation.

$$
\operatorname{Dr}=\frac{S e d+C e d}{\sum(S+C)}
$$

Where: $\mathrm{Dr}$ is the dispersion ratio, $\mathrm{S}_{\text {ed }}$ is easily dispersible silt in the soil; $\mathrm{C}_{\mathrm{ed}}$ is easily dispersible clay in the soil, $\mathrm{S}$ is silt in the soil and $\mathrm{C}$ is clay in the soil.

The easily dispersible silt and clay were found out by taking $10 \mathrm{gm}$ of $10 \mathrm{mesh}(2 \mathrm{~mm})$ sieved soil in an open mouth measuring cylinder and gently shaking after making the volume to 1000 C.C by distilled water. Out of this, after allowing proper time for setting in proportion to room temperature [22], a portion was pipetted out, dried, and weighed to a constant weight. This gives the amount of easily dispersible (silt +clay) in the sample. The total silt +clay in the soil were determined by mechanical analysis. Erosion index was worked out by the following expression (4) as suggested by [23].

$$
\mathrm{E}=\frac{D r}{C / 0.5 w h c}
$$

Where: EI is the erosion index, $\mathrm{C}=$ clay, whc= water holding capacity which was determined using a pressure plate apparatus.

\section{Data Analysis}

The data collected for different parameters related to a physicochemical property of soil were statistically analyzed using analysis of variance for 7 replications of RCBD was computed using SAS to see if there was a significant difference between the treatment means for the various variables. Least significance difference was used to separate means from each other among the locations using the 5\% probability level. Pearson correlation coefficient was used to show the relationship and significance of the recorded soil characteristics. 


\section{Resutls and Discussion}

Textural Classification of the Experimental Plots

Table 1. Particle distribution (\%) of the soil as affected by conservation structure.

\begin{tabular}{|c|c|c|c|c|c|c|c|c|c|c|c|}
\hline \multirow{3}{*}{$\begin{array}{l}\text { Treatment } \\
\text { North-Ballesa-on } \\
\end{array}$} & \multicolumn{3}{|c|}{ Upper position } & \multirow[t]{2}{*}{ Texture } & \multicolumn{3}{|c|}{ Middle position } & \multirow[t]{2}{*}{ Texture } & \multicolumn{3}{|c|}{ Lower positic } \\
\hline & & & & & & & & & & & \\
\hline & Clay & Silt & Sand & & Clay & Silt & Sand & & Clay & Silt & $\mathrm{S}$ \\
\hline Level bund & 20 & 40 & 40 & Loam & 21 & 41 & 38 & Loam & 32 & 45 & \\
\hline Level fanya juu & 18 & 42 & 40 & Loam & 20 & 42 & 38 & Loam & 22 & 45 & \\
\hline Control & 18 & 22 & 60 & Sandy Loam & 19 & 23 & 58 & Sandy Loam & 18 & 43 & \\
\hline \multicolumn{12}{|c|}{ North-Ballesa-two } \\
\hline Level bund & 20 & 40 & 40 & Loam & 21 & 42 & 37 & Loam & 22 & 63 & \\
\hline Level fanya juu & 21 & 40 & 39 & Loam & 21 & 40 & 39 & Loam & 22 & 45 & \\
\hline Control & 18 & 40 & 42 & Loam & 21 & 42 & 37 & Loam & 16 & 45 & \\
\hline \multicolumn{12}{|c|}{ Ana-Ballesa-three } \\
\hline Level bund & 16 & 53 & 31 & Silt Loam & 18 & 54 & 38 & Loam & 23 & 53 & \\
\hline Level fanya juu & 20 & 45 & 35 & Loam & 23 & 47 & 30 & Loam & 24 & 49 & \\
\hline Control & 16 & 30 & 54 & Sandy Loam & 17 & 38 & 45 & Loam & 18 & 42 & \\
\hline \multicolumn{12}{|c|}{ Ana-Bal1esa-four } \\
\hline Level bund & 18 & 40 & 42 & Loam & 19 & 41 & 40 & Loam & 20 & 43 & \\
\hline Level fanya juu & 16 & 40 & 44 & Loam & 20 & 41 & 39 & Loam & 22 & 42 & \\
\hline Control & 14 & 26 & 60 & Sandy Loam & 18 & 28 & 54 & Sandy Loam & 18 & 41 & \\
\hline \multicolumn{12}{|c|}{ Ana-Ballesa-five } \\
\hline Level bund & 18 & 40 & 42 & Loam & 20 & 42 & 38 & Loam & 21 & 43 & \\
\hline Level fanya juu & 17 & 40 & 43 & Loam & 18 & 42 & 40 & Loam & 20 & 44 & \\
\hline Control & 16 & 41 & 43 & Loam & 17 & 42 & 41 & Loam & 18 & 44 & \\
\hline \multicolumn{12}{|l|}{ Amibicho-six } \\
\hline Level bund & 21 & 20 & 59 & Sandy Loam & 24 & 40 & 36 & Loam & 30 & 43 & \\
\hline Level fanya juu & 19 & 34 & 47 & Loam & 20 & 39 & 41 & Loam & 24 & 42 & \\
\hline Control & 18 & 26 & 56 & Sandy Loam & 18 & 27 & 55 & Sandy Loam & 19 & 36 & \\
\hline \multicolumn{12}{|l|}{ Amibicho-seven } \\
\hline Level bund & 20 & 38 & 42 & Loam & 20 & 40 & 40 & Loam & 26 & 44 & \\
\hline Level fanya juu & 18 & 38 & 44 & Loam & 20 & 41 & 39 & Loam & 32 & 42 & \\
\hline Control & 18 & 22 & 60 & Sandy Loam & 18 & 24 & 58 & Sandy Loam & 20 & 36 & \\
\hline
\end{tabular}

Texture was affected both by position of the land relative to the structure within the same conservation structure and by the different soil conservation structures. Analysis of variance showed that the content of sand, silt, and clay were significantly affected by the position and location of conservation structures (Tables 1 and 3). Sand and clay are significantly $(\mathrm{P} \leq 0.05)$ affected by treatment alone, whereas silt was affected by treatment and location (Tables 2 and 3)

Higher contents of silt were determined at the lower position than in the upper and middle position, showing that the silt is more sensitive to erosion from the upper and middle position and accumulated at on the lower position for all locations (Table 1) Silt sized particles are small enough to reduce the permeability of soil and are also easily carried by runoff. The mean contents of clay, silt, and sand of the control plots were significantly lower and higher $(\mathrm{p} \leq 0.05)$ than the mean contents of level bund and level fanya juu respectively (Table 2). [24] Studied soils in a topo sequence of terraced (down- and midslope) and to none terraced land (up-slope) in the Hagere-selam uplands in Degua Tembien, Tigray. Surface soils from terrace benches had the highest clay contents, while soils from non-terraced land were sandy. 
Table 2. Comparison between treatments versus soil type.

\begin{tabular}{|c|c|c|c|c|c|c|}
\hline \multirow{2}{*}{ Treatment } & \multicolumn{2}{|c|}{ Clay (\%), } & \multicolumn{2}{|c|}{ Silt (\%), } & \multicolumn{2}{|c|}{ Sand (\%), } \\
\hline & Mean & Std & Mean & Std & Mean & Std \\
\hline Level bund & $21.429 a$ & $3.67^{*}$ & $43.095 \mathrm{a}$ & $8.91^{*}$ & $35.95 a$ & $12.29^{*}$ \\
\hline $\begin{array}{l}\text { Level Fanya } \\
\text { juu }\end{array}$ & $20.333 a$ & $2.57^{*}$ & $41.905 a$ & $7.72^{*}$ & $37.29 a$ & $10.95^{*}$ \\
\hline Control & $17.762 \mathrm{~b}$ & - & $34.19 b$ & - & $48.24 \mathrm{~b}$ & \\
\hline LSD (0.05) & \multicolumn{2}{|c|}{1.62} & \multicolumn{2}{|c|}{3.65} & \multicolumn{2}{|c|}{4.86} \\
\hline CV (\%) & \multicolumn{2}{|c|}{13.09} & \multicolumn{2}{|c|}{14.75} & \multicolumn{2}{|c|}{19.22} \\
\hline
\end{tabular}

N.B. *Significant at ( $\mathrm{p} \leq 0.05)$, and means in a column followed by the same letter are not significantly different. (Source: analysis results)

As it is seen from (Table 2), water erosion in the study area resulted a reduction in the soil depth and affected the texture of the plough layer in the interstructural areas of level fanya juu and control plot by taking the original soil material and leaving uncovered coarser soil particles in the sub-soil layers. From the analysis of variance (Table 2), clay, silt, and sand are significant at $(\mathrm{p} \leq 0.05)$ by location and position. On the other hand, clay and sand were significantly affected $(\mathrm{P} \leq 0.05)$ by conservation structures, not by location (Table 3).

The average clay and sand content recorded in the level bund and level Fanya juu are significantly higher and lower $(p \leq 0.05)$ than the average clay and sand content of the control plot respectively (Table 2). The amount of soil erosion which occurs under a given conditions is, however, influenced not only by the soil itself, but by the treatment or management it receives [25]. The low clay content and the high sand available in the control plot show the higher extent of erosion in the study area which affected the unmanaged plots than managed plots. The results of this study are in conformity with the findings reported by [26] showing that erodibility (erosion intensity) is positively and significantly correlated with high sand content.

Table 3. Comparison of means of soil separates as deduced by location.

\begin{tabular}{cccc}
\hline Locations & Clay\% & Silt $\%$ & Sand \% \\
\hline North-Belesa-one & $20.889 \mathrm{a}$ & $38.11 \mathrm{~b}$ & $41.00 \mathrm{~b}$ \\
Ana-Ballesa-three & $19.444 \mathrm{~b}$ & $45.667 \mathrm{a}$ & $36.00 \mathrm{~b}$ \\
Ana-Ballesa-four & $18.333 \mathrm{~b}$ & $38.00 \mathrm{~b}$ & $43.667 \mathrm{a}$ \\
Ana-Ballesa-five & $18.333 \mathrm{~b}$ & $42.00 \mathrm{~b}$ & $39.667 \mathrm{~b}$ \\
Ambicho-six & $21.444 \mathrm{a}$ & $34.11 \mathrm{~b}$ & $44.889 \mathrm{a}$ \\
Ambicho-seven & $20.222 \mathrm{~b}$ & $36.11 \mathrm{~b}$ & $42.556 \mathrm{~b}$ \\
\hline LSD $(0.05)$ & 2.47 & 5.576 & 7.4 \\
\hline
\end{tabular}

N.B. Means with in columns followed by the same letter are not significantly different at ( $\mathrm{p} \leq 0.05)$. (Source: analysis results).

Significant difference was observed between location one; six and the other five locations in clay content. There was also a significant difference between locations six; four and the other five locations in sand content in the study area (Table 3). Lower sand contents were seen in level bund and level fanya juu treated plots than the control plots. Furthermore, soils with a low proportion of sand accumulated more organic matter than soils with a high proportion of sand in a relatively wetter climate, as in the case of the study area [27]. Soils of low organic content are subjected to comparatively rapid erosion; usually they have less retentive of moisture [28]. Coarse texture is usually associated with a single-grain structure (particles separated, that is, not clustered in granules or aggregates).

Sandy soils are susceptible to erosion for rain drop removal due to their low consistency and large particles that can no longer resist the kinetic energy of rain splash, according to studies on the effects of soil texture on the erosion process [29]. Significant difference at $(\mathrm{P} \leq 0.05)$ was observed among the conservation structures and location of silt content (Table 3). Primary soil particles, particularly clays, tend to cohere under natural 
conditions to form secondary units called aggregates. The ability of these secondary units to resist breakdown when wet is important for maintaining a high permeability to water and air. The size of the aggregates determines their susceptibility to movement (erosion) by water.

\section{Bulk Density, Total Porosity and Available Water}

Measurements made for bulk density on the experimental plots of treated and untreated showed that there were no significant differences observed between level bund and level fanya juu (Table 4). The mean bulk density of level bund treated plot is lower $(\mathrm{P} \leq 0.05)$ than the level fanya juu and the control plot and the level fanya juu is significantly lower than the unprotected plot as the bulk density decreases with increasing clay content in soil. It is expected that water retention also increases with decreasing bulk density. The total porosity of sandy soils is less than that of fine textured soils [22]. These variations result mostly from differences in total pore space such that the finer texture soils have more pore space and lower bulk density than sandy soils. Organic matter decreases bulk density in two ways, first, organic matter is much lighter in weight than the corresponding volume of mineral matter; second, organic matter gives increased aggregate stability to a soil. Moreover bulk density increases when cultivation causes a loss in organic matter from soil [22]. An increase in bulk density on the control plot of this study was due to poor management. Runoff and erosion loss of soil and nutrients can be caused by excessive bulk density when surface water is restricted from moving through the soil.

As indicated on (Table 5), the porosity of the soil was statistically significant $(\mathrm{P} \leq 0.05)$ among the selected conservation structures and locations. On level bund and level fanya juu plots, the total pore volume was significantly higher (P0.05) than on control plots (Table 4) There is no significant difference between the level bund and fanya juu, but there is a significant difference between the control plots and the selected conservation structures. The low average pore volume in the control plot was because of soil degradation due to removal of soil organic matter and exposure of subsoil by water erosion in the study area. The importance of soil organic matter to soil porosity, particularly its contribution to the proportion of large pores in clay-dominated soils, is well documented by [22].

The control plot had the lowest total pore volume (45.516\%) (Table 4), This low total porosity in the control plot is due to the study area's low organic carbon, low organic matter, and high bulk density values (Tables 4 and 5). This finding was supported by [30] due to top soil removal and exposure of subsoil, a $26 \%$ decrease in total porosity was known. Sandy soils usually have less pore space than finely textured soils.

Table 4. Comparison of treatments versus soil physical properties.

\begin{tabular}{|c|c|c|c|c|c|c|}
\hline \multirow[t]{2}{*}{ Treatment } & \multicolumn{2}{|c|}{ Bulk density gm/ $\mathrm{cm}^{3}$, } & \multicolumn{2}{|c|}{ Porosity $(\%)$} & \multicolumn{2}{|c|}{$\begin{array}{c}\text { Available water holding } \\
\text { capacity }\end{array}$} \\
\hline & Mean & Std & Mean & Std & Mean & Std \\
\hline Level bund & $1.381 a$ & $0.016^{*}$ & $47.565 a$ & $2.049^{*}$ & $17.8452 \mathrm{a}$ & $5.25^{*}$ \\
\hline $\begin{array}{l}\text { Level fanya } \\
\text { juu }\end{array}$ & $1.383 a$ & $0.014^{*}$ & $47.052 b$ & $1.536^{*}$ & $17.4233 a$ & $4.83^{*}$ \\
\hline Control & $1.399 b$ & & $45.516 c$ & - & $12.591 b$ & - \\
\hline LSD (0.05) & \multicolumn{2}{|c|}{0.0082} & \multicolumn{2}{|c|}{0.474} & \multicolumn{2}{|c|}{1.536} \\
\hline $\mathrm{CV} \%$ & \multicolumn{2}{|c|}{0.9434} & \multicolumn{2}{|c|}{1.6298} & \multicolumn{2}{|c|}{15.46} \\
\hline
\end{tabular}

* Significant at $(\mathrm{P} \leq 0.05)$, and Means in a column followed by the same letter are not significantly different at $(\mathrm{P} \leq 0.05)$. (Source: analysis results).

Available soil water (ASW) is the amount of water available for uptake by plants, which is held at suctions between the wilting point and field capacity. It varies with soil type and can be correlated with the clay content and structural arrangement of the soil. It varies also with soil treatment because the size and distribution of pores in the topsoil reflects surface exposure, normal seasonal wetting, and drying, and management. According to the available water, the holding capacity in the soil increases as the porosity of 
soil increases and the bulk density decreases (Table 4). Study by [31] of the water content of 244 soil samples, found that the (ASW) of well-structured soils was one-third to twice as large as that in comparable (similarly-textured) poorly structured or degraded soils. Bearing in mind that ASW varies with natural weathering and management, (Table 4) gives typical values of a for different treatments selected.

Table 5. Comparison of means of location versus soil physical properties.

\begin{tabular}{cccc}
\hline Location & $\begin{array}{c}\text { Bulk density } \\
\left(\mathbf{g m} / \mathbf{c m}^{\mathbf{3}}\right),\end{array}$ & Porosity (\%), & $\begin{array}{c}\text { Available water } \\
\text { holding capacity (\%), }\end{array}$ \\
\hline North Belesa-one & $1.4067 \mathrm{a}$ & $46.8556 \mathrm{~b}$ & $15.788 \mathrm{a}$ \\
North Belesa-two & $1.3789 \mathrm{~d}$ & $47.40 \mathrm{a}$ & $15.06 \mathrm{a}$ \\
Ana Belesa-three & $1.3856 \mathrm{c}$ & $47.3778 \mathrm{a}$ & $16.117 \mathrm{a}$ \\
Ana Belesa-four & $1.4011 \mathrm{~b}$ & $46.4078 \mathrm{c}$ & $16.532 \mathrm{a}$ \\
Ana Belesa-five & $1.39 \mathrm{c}$ & $45.9844 \mathrm{c}$ & $16.128 \mathrm{a}$ \\
Ana Belesa-six & $1.3767 \mathrm{~d}$ & $45.8478 \mathrm{c}$ & $15.929 \mathrm{a}$ \\
Ambicho- seven & $1.3756 \mathrm{~d}$ & $47.1044 \mathrm{~b}$ & $16.119 \mathrm{a}$ \\
LSD (0.05) & 0.0125 & 0.7243 & 2.346 \\
\hline
\end{tabular}

(Source: analysis results).

Bulk density of North Belesa-one is significantly different from the other six locations, whereas there is no significant different between locations on the available water holding capacity.

\section{Organic Matter, Organic Carbon and Soil pH}

The amount of organic matter contained in a soil is important with respect to erodibiltity; and soil structure. Almost all soils of low organic matter content are subject to comparatively rapid erosion; [28]. Supplying plant nutrients is one of the important functions of organic matter in soil. Another is to help bind the mineral particles into aggregate units providing an open structure with adequate pore space for good aeration. Control plot has a relatively smaller organic matter content value (2.973) than level bund and level fanya juu (Table 6). Because of that, it is exposed to erosion. Most soils contain between 1 and 6 percent organic matter. Relatively small amount of organic matter was shown on North Belessa sample one; two, Ana Ballesa four, five and Ambicho seven was due to erosion. Whereas the other locations has higher amount of organic matter which is helpful in overcoming the problem of too much water in clay soil as it is a problem of too little water in a sandy soil as it is. Organic matter helps to hold the clay particles together in clusters that have air space between them, hence the location which have high organic matter content, are rich in clay and good in drainage.

Soil $\mathrm{pH}$ is an important consideration for farmers and gardeners for several reasons; including the fact that many plants and soil life forms prefer either alkaline or acidic conditions, that some diseases tend to thrive when the soil is alkaline or acidic, and that the $\mathrm{pH}$ can affect the availability of nutrients in the soil. By strict definition, any $\mathrm{pH}$ below 7 is acid and any $\mathrm{pH}$ above 7 is alkaline. The mean $\mathrm{pH}$ of the soils sampled from untreated and treated plots of all locations are found between 5.86 and 6.405 which are slightly acid with level fanya juu and level bund and control plots approaching medium acid, (Table 6). The average $\mathrm{pH}$ of the control plot was smaller than those of the treated plots. This is because of the removal of base by leaching processes from the soil and therefore tends to lower the $\mathrm{pH}$ with time [22]. The $\mathrm{pH}$ is significantly higher on level fanya juu and level bund than the control plot. The relative higher average $\mathrm{pH}$ at the level bund and level fanya juu treated plots than the control plot can be explained by the difference in the extent of soil loss between the control level bund and level fanya juu treated plots. This was also confirmed by [1] who found that the higher amount of soil loss due to erosion might have had removed the topsoil and exposed the subsoil to the surface resulting in lower $\mathrm{pH}$. Leaching processes are accelerated under acid conditions because more cations are released by acid weathering and fewer are held by cation exchange [22]. Hence, the control 
plot is approaching medium acid because there is higher leaching process than level bund and level fanya juu treated plots. The low organic carbon reflected in the unprotected plots was also due to extensive leaching of base cations and rapid development of acidity.

Table 6. Comparison of treatments versus soil chemical properties.

\begin{tabular}{|c|c|c|c|c|c|c|}
\hline \multirow[t]{2}{*}{ Treatment } & \multicolumn{2}{|c|}{ pH value, } & \multicolumn{2}{|c|}{ Organic matter $(\%)$, } & \multicolumn{2}{|c|}{ Organic carbon (\%), } \\
\hline & Mean & Std & Mean & Std & Mean & Std \\
\hline Level bund & $6.405 a$ & $0.545^{*}$ & $3.621 a$ & $0.648^{*}$ & $2.098 \mathrm{a}$ & $0.649^{*}$ \\
\hline $\begin{array}{c}\text { Level fanya } \\
\text { juu }\end{array}$ & $6.129 a$ & $0.269^{*}$ & $3.663 a$ & $0.69^{*}$ & $1.962 \mathrm{a}$ & $0.513^{*}$ \\
\hline Control & $5.86 \mathrm{~b}$ & - & $2.973 b$ & - & $1.449 \mathrm{~b}$ & - \\
\hline LSD (0.05) & \multicolumn{2}{|c|}{0.157} & \multicolumn{2}{|c|}{0.2875} & \multicolumn{2}{|c|}{0.2738} \\
\hline $\mathrm{CV} \%$ & \multicolumn{2}{|c|}{4.11} & \multicolumn{2}{|c|}{13.515} & \multicolumn{2}{|c|}{23.98} \\
\hline
\end{tabular}

N.B. The starred values in the column indicate pairs of means that are significantly different.

Means with the same letter in the column are not significantly different. (Source: analysis results).

The smallest $\mathrm{pH}$ (5.99) was observed in Ana Ballesa three (Table 7), which is the most erodeded based on the above physical characteristics. Usually the optimum $\mathrm{pH}$ is somewhere between 6 and 7.5 because all plant nutrients are reasonably available in this range. The $\mathrm{pH}$ of the soil influences the rate at which plant nutrients are released by weathering, the solubility of all soil materials, and the amount of nutrients stored on cation exchange sites [22]. Thus, the availability of nitrogen, potassium and phosphorus is between $\mathrm{pH} 6$ and 8 .

Table 7. Comparison of location versus $\mathrm{pH}$ values, between organic carbon and organic matter.

\begin{tabular}{cccc}
\hline Location & $\mathrm{pH}$ & Organic matter \% & Organic carbon \% \\
\hline North belesa-one & $6.21 \mathrm{~b}$ & $3.44 \mathrm{c}$ & $1.94 \mathrm{a}$ \\
North-Belesa-two & $6.24 \mathrm{a}$ & $3.05 \mathrm{c}$ & $1.67 \mathrm{a}$ \\
Ana-Belesa-three & $5.99 \mathrm{~b}$ & $3.51 \mathrm{~b}$ & $1.68 \mathrm{a}$ \\
Ana-Belesa-four & $6.11 \mathrm{~b}$ & $3.21 \mathrm{c}$ & $1.90 \mathrm{a}$ \\
Ana-Belesa-five & $6.14 \mathrm{~b}$ & $3.42 \mathrm{c}$ & $1.83 \mathrm{a}$ \\
Ambicho-six & $6.06 \mathrm{~b}$ & $3.88 \mathrm{a}$ & $1.90 \mathrm{a}$ \\
Ambicho-seven & $6.16 \mathrm{~b}$ & $3.41 \mathrm{c}$ & $1.90 \mathrm{a}$ \\
LSD $(0.05)$ & 0.2397 & 0.4391 & 0.418 \\
\hline
\end{tabular}

N.B Means with the same letter in the column are not significantly different (Source: analysis results).

The chemically active form of carbon in the soil is of higher interest than the other forms. This includes the immediate decomposition of products of raw organic material and soil humus. In this study, the selected conservation structures affected significantly $(\mathrm{P} \leq 0.05)$ soil organic carbon; soil $\mathrm{pH}$, soil organic matter, available potassium, available phosphorous, cation exchange capacity and total nitrogen. The organic carbon content of all soil samples was between $0.56 \%$ and $2.73 \%$. The level bund treated plot had higher and significant organic carbon followed by level fanya juu than the control plot. The mean organic carbon content for level bund, level fanya juu, and control plot were 2.098\%, $1.962 \%$, and $1.449 \%$, respectively (Table 6). These values indicated as an increment of $47.79 \%$ and $35.4 \%$ of organic carbon in the respective structures than the control plot. Even if the coefficient of variance for organic carbon was greater than twenty, the model explained the three variables almost to the same level.

Studies of [32] exist that calibrate the contribution of various individual, site-specific conservation practices on changes in soil organic carbon. There is a general absence, however, of a comprehensive effort to measure objectively the contribution of these practices including conservation tillage, the Conservation Reserve Programme, and conservation 
buffer strips to a change in soil organic carbon. However, this was done in US after recounting the evolution of the use of various conservation practices like terraces, soil bunds, etc, it is estimated that the organic carbon in the soil in 1998 in the United States attributable to these practices was about 12.2 million metric tons. By 2008 , there will be an increase of about $25 \%$. Given that there is a significant potential for conservation practices to lead to an increase in carbon seqestration. In addition this result was in conformity with the findings of [33] who observed increased organic carbon in the conservation treated plots compared to untreated plots and the study by [34] confirmed it by his findings that an increased organic carbon in treated plots than control plots.

\section{Erodibility, Dispersion Ratio and Erosion Index}

In the present investigation, the soils in the level bund and level Fanya juu treated plots had significantly lower $(\mathrm{P} \leq 0.05)$ erodibility proportionality ratio than the control plots (Table 8) This shows that soils in the control plots are more erodibile than the conservation treated plots as also reported by [35]. This indicates that the amount of soil erosion which occurs under a given conditions is, however, influenced not only by the soil itself, but by the treatment or management it receives. Erodibility proportionality of location four was significantly different from the other six locations (Table 9). This was due to the particle size distribution in the control plot.

Table 8. Comparison of treatment versus erodibility, desperation ratio, and erosion index.

\begin{tabular}{ccccccc}
\hline \multirow{2}{*}{ Treatment } & \multicolumn{2}{c}{ Erodibility } & \multicolumn{2}{c}{ Dispersion ratio } & \multicolumn{2}{c}{ Erosion index } \\
\cline { 2 - 7 } & Mean & Stv & Mean & Stv & Mean & Stv \\
\hline Level bund & $4.4 .3 \mathrm{a}$ & \multirow{2}{*}{$0.89^{*}$} & $70.10 \mathrm{a}$ & $8.47^{*}$ & \multirow{2}{*}{$4.4 .3 \mathrm{a} 19.23 \mathrm{a}$} & $6.28^{*}$ \\
Level fanya & $3.816 \mathrm{a}$ & & & & & \\
juu & $3.93 \mathrm{a}$ & $0.78^{*}$ & $71.72 \mathrm{a}$ & $6.85^{*}$ & $20.24 \mathrm{a}$ & $5.27^{*}$ \\
Control & $4.71 \mathrm{~b}$ & & $78.57 \mathrm{~b}$ & - & $25.51 \mathrm{~b}$ & \\
LSD (0.05) & \multicolumn{2}{c}{0.389} & \multicolumn{2}{c}{2.92} & \multicolumn{2}{c}{2.16} \\
CV (\%) & \multicolumn{2}{c}{15.054} & \multicolumn{2}{c}{6.38} & \multicolumn{2}{c}{16.02} \\
\hline
\end{tabular}

N.B. The starred value in the table indicates pairs of means that are significantly different. Means with the same letter in the column are not significantly different. (Source: analysis results).

This might be due to the amount and cumulative effects of the other elements in the soil and the difference in texture. Relatively highest erodibility proportionality ratio was observed on Ana Ballesa four (4.54\%) and the lowest erodibility proportionality ratio on Amibicho six (3.79\%) (Table 9). In this study, the soils on the level bund and level Fanya Juu had significantly lower $(\mathrm{P} \leq 0.05)$ dispersion ratio than the control plots (Table 8$)$. Dispersion ratio was significantly different between North Ballesa one and two, and the other five locations (Table 9). The highest dispersion ratio (76.48) was observed in North Ballesa one while the lowest was recorded in Ana Ballesa four (69.78). This was due to the textural variation of the control plot in the areas. The level bund and the level fanya juu are comparatively more resistant to erosion than the control plots due to the treatment the soils received. From (Table 8), the control plots had the highest dispersion ratio (78.57) which shows the highest susceptibility to erosion. This finding was supported by [36], who confirmed that management influences erodibility more than any other factor, and defined decision of crop management. 
Table 9. Comparison of location versus erodibility, dispersion ratio, and erosion index.

\begin{tabular}{lcccc}
\hline \multicolumn{1}{c}{ Location } & & Erodibility & Dispersion ratio & Erosion index \\
\hline North Ballesa & $\mathrm{R}_{1}$ & $3.93 \mathrm{~b}$ & $76.48 \mathrm{a}$ & $24.83 \mathrm{a}$ \\
North-Ballesa & $\mathrm{R}_{2}$ & $4.19 \mathrm{~b}$ & $74.68 \mathrm{a}$ & $20.87 \mathrm{~b}$ \\
Ana-Ballesa & $\mathrm{R}_{3}$ & $4.26 \mathrm{~b}$ & $74.19 \mathrm{~b}$ & $20.29 \mathrm{~b}$ \\
Ana-Ballesa & $\mathrm{R}_{4}$ & $4.54 \mathrm{a}$ & $69.78 \mathrm{~b}$ & $21.02 \mathrm{~b}$ \\
Ana-Ballesa & $\mathrm{R}_{5}$ & $4.49 \mathrm{~b}$ & $72.51 \mathrm{~b}$ & $22.57 \mathrm{~b}$ \\
Ambicho & $\mathrm{R}_{6}$ & $3.79 \mathrm{c}$ & $73.232 \mathrm{~b}$ & $20.56 \mathrm{~b}$ \\
Ambicho & $\mathrm{R}_{7}$ & $3.85 \mathrm{c}$ & $73.4 \mathrm{~b}$ & $21.48 \mathrm{~b}$ \\
LSD (0.05) & & 0.595 & 4.457 & 3.33 \\
\hline
\end{tabular}

N.B. Means with the same letter in the column are not significantly different. (Source: analysis results).

Like dispersion ratio, the highest value was observed in the control plots (25.51) whereas the lowest was recorded by level bund (19.23) followed by level fanya juu (20.24) (Table 8). An increase in surface soil dispersibility increases erodibility, this in turn enhanced by ESP (exchangeable sodium percentage) [37]. From (Table 9), the lowest value (20.29) of erosion index was observed in Ana-Ballesa three and the highest (24.83) was observed in North-Ballesa one. There is a significant difference in erosion index between location one and the other six locations (Table 9). This might be due the difference in texture and the amount and cumulative effect of other elements of the soil.

\section{Cation Exchange Capacity and Soil Nutrients}

When soil is removed from the field, both available and potential plant food, along with inert mineral material and everything composing the body of the soil, is carried away (Table 10). According to (Table 10), level bund and level fanya juu structures had higher values of cation exchange capacity (CEC) (27.75) and (25.45 meq/100g) respectively than the control plots (21.03meq/100gram). This is because the exchange capacity of soil depends on the percentage of humus it contains and on the percentage composition of its clay; this is also due to the leaching problem on control plot soils with a low CEC can only hold a small quantity of nutrients on the exchange sites. The nutrients applied to the soil that exceed this amount can easily be leached out by excess rain.

Table 10. Comparison of treatment versus CEC and soil minerals.

\begin{tabular}{|c|c|c|c|c|c|c|c|c|}
\hline \multirow{2}{*}{$\begin{array}{c}\text { Treatmen } \\
\mathbf{t}\end{array}$} & \multicolumn{2}{|c|}{ CEC (meq/100gr), } & \multicolumn{2}{|c|}{ Total Nitrogen $(\%)$, } & \multicolumn{2}{|c|}{$\begin{array}{c}\text { Available potassium } \\
\mathrm{mg} / \mathrm{kg},\end{array}$} & \multicolumn{2}{|c|}{$\begin{array}{c}\text { Available } \\
\text { phosphorus (ppm), }\end{array}$} \\
\hline & Mean & Std & Mean & Std & Mean & Std & Mean & Std \\
\hline $\begin{array}{l}\text { Level } \\
\text { bund }\end{array}$ & $27.75 \mathrm{a}$ & $6.72^{*}$ & $0.2 \mathrm{a}$ & $0.036^{*}$ & $15.71 \mathrm{a}$ & $3.28^{*}$ & $5.77 \mathrm{a}$ & $1.8^{*}$ \\
\hline $\begin{array}{c}\text { Level } \\
\text { fanya juu }\end{array}$ & $25.45 b$ & $4.42^{*}$ & $0.185 \mathrm{a}$ & $0.021^{*}$ & $14.06 \mathrm{a}$ & $1.63 *$ & $5.18 \mathrm{~b}$ & $1.21^{*}$ \\
\hline Control & $21.03 \mathrm{c}$ & - & $0.164 b$ & - & $12.43 b$ & - & $3.97 \mathrm{c}$ & - \\
\hline $\operatorname{LSD}(0.05)$ & \multicolumn{2}{|c|}{2.153} & \multicolumn{2}{|c|}{0.0074} & \multicolumn{2}{|c|}{1.07} & \multicolumn{2}{|c|}{.5045} \\
\hline $\mathrm{CV}(\%)$ & \multicolumn{2}{|c|}{13.97} & \multicolumn{2}{|c|}{6.525} & \multicolumn{2}{|c|}{12.2} & \multicolumn{2}{|c|}{16.29} \\
\hline
\end{tabular}

N.B. The starred values in the columns are pairs of means which are significantly different.

(Source: analysis results).

In this study, conservation structures significantly affected $(P \leq 0.05)$ cation exchange capacity, available phosphorus, available potassium and total nitrogen. There is a significant difference of cation exchange capacity among the locations of North-Ballesa sample one; Ana-Ballesa sample three and the other five locations (Table 11). This is due to the particle size distribution in the study area. It is not surprising that nitrogen is the most widely applied fertilizer element. The concentration of nitrogen in igneous rocks is so low that it can meet plant needs. The atmosphere is $78 \%$ nitrogen but this nitrogen cannot be used for higher it cannot meet plants until it is chemically combined with hydrogen, oxygen or carbon [22]. The average total nitrogen observed in the plots under conservation 
treated land is between $0.164 \%$ and $0.2 \%$ (Table 10). As shown in (Table 11), there is a significant difference in total nitrogen among each location and position $(\mathrm{P} \leq 0.05)$.

Table 11. Comparison of location versus CEC and soil minerals.

\begin{tabular}{ccccc}
\hline Location & CEC meq/100gr & $\begin{array}{c}\text { Total Nitrogen } \\
\mathbf{( \% )}\end{array}$ & $\begin{array}{c}\text { Available } \\
\text { Potassium mg/kg }\end{array}$ & $\begin{array}{c}\text { Available } \\
\text { Phosphorus } \\
\text { (ppm) }\end{array}$ \\
\hline North Ballesa-1 & $26.3 \mathrm{a}$ & $0.1789 \mathrm{~b}$ & $13.98 \mathrm{~b}$ & $5.189 \mathrm{a}$ \\
North Ballesa-2 & $23.73 \mathrm{~b}$ & $0.1833 \mathrm{~b}$ & $14.26 \mathrm{~b}$ & $4.9 \mathrm{a}$ \\
Ana Ballesa-3 & $26.34 \mathrm{a}$ & $0.1889 \mathrm{a}$ & $14.11 \mathrm{~b}$ & $4.678 \mathrm{a}$ \\
Ana Ballesa-4 & $24.23 \mathrm{~b}$ & $0.1844 \mathrm{~b}$ & $15.04 \mathrm{a}$ & $4.97 \mathrm{a}$ \\
Ana Ballesa-5 & $26.83 \mathrm{~b}$ & $0.1767 \mathrm{~b}$ & $14.15 \mathrm{~b}$ & $4.99 \mathrm{a}$ \\
Ambicho-6 & $23.8 \mathrm{~b}$ & $0.1822 \mathrm{~b}$ & $13.12 \mathrm{~b}$ & $4.856 \mathrm{a}$ \\
Ambicho-7 & $22.94 \mathrm{~b}$ & $0.1878 \mathrm{~b}$ & $13.78 \mathrm{~b}$ & $5.211 \mathrm{a}$ \\
LSD (0.05) & 3.2886 & 0.0114 & 1.63 & 0.771 \\
\hline
\end{tabular}

N.B. CEC (cation exchange capacity), N (Nitrogen), K (Potassium), P (Phosphorus). Means with the same letter in the column are not significantly different at (P $\leq 0.05)$. (Source: analysis results).

For the control plot, the lowest value $(0.164)$ for mean Nitrogen was observed, while the highest (0.2) and (0.185) were observed for level bund and level fanya juu, respectively (Table 10). This demonstrates that the conservation treated plots retain more nitrogen than the control plots because the treatments retain more organic matter and the organic matter held in the control plot was quickly released due to the soil's medium acidity. As stated by [38], organic matter content occurs mostly in either partly humified still recognizable particles or in humified components associated with clay minerals and similar to the finding which was consistent with that of [39] who found top soil removal resulted in reduced total nitrogen available phosphorus and potassium content of the top $10 \mathrm{~cm}$ of the soil through the loss of organic matter [40]. Moreover showed that the lowest nitrogen value was observed on control plots whereas the highest were recorded on level fanya juu and level bund, respectively.

Potassium is the third most likely nutrient element to limit plant growth and is therefore a widespread constituent of fertilizers. Nitrogen, phosphorus, and potassium are all components of a complete fertilizer. Potassium occurs in soil as potassium ions in mineral structures and as hydrated potassium ions in solution or absorbed on cation exchange sites [22].

Available potassium content as shown in (Table 10) varies from $12.43 \mathrm{mg} / \mathrm{kg}$ of soil, $15.71 \mathrm{mg} / \mathrm{kg}$ of soil. This value is affected by the conservation structure showing the highest value $15.71 \mathrm{mg} / \mathrm{kg}$ for level bund, $14.06 \mathrm{mg} / \mathrm{kg}$ for level fanya juu, and $12.43 \mathrm{mg} / \mathrm{kg}$ for control plots. The smallest value for the control plot is caused by the leaching effect on the plot. The analysis of variance (Table 10) showed that the amount of available potassium was significantly affected $(\mathrm{P} \leq 0.05)$ by conservation measures. There is a significant difference between conservation structures and control plots. However, there is no significant difference between level bund and level fanya juu (Table 10).

The relatively high amount of available potassium in the level bund and level fanya juu was due to the high organic matter and organic carbon content of these plots. This is also because the control plots have a relatively high amount of sand. Sand has low cation exchange capacity and therefore has small exchangeable potassium. The sand particles weather very slowly and therefore are slow to release potassium [22]. A significant difference in potassium content was observed between the locations of Ana-Ballesa-four and the other six locations (Table 11). This is probably due to land management like level bund and level fanya juu construction, cultivation practices, and erosive agents such as runoff.

The low level of potassium in the control plot is due to the plant uptake of potassium from the root zone where as other treatments get additional potassium from organic matter. [41] the found uptake of potassium by wheat growing soil exceeded the available potassium content of the soil. The removal of potassium by crop growth and the loss caused by leaching are also the main causes for low levels of potassium on the control plots [22]. 
The lowest amount of potassium in the control plot is also due to the low amount of cation exchange capacity in the control plot (Table 10).

The mean available phosphorus contents of the soils sampled from the seven locations as affected by conservation structures vary between 4.678 and 5.211 ppm (Table 11). Based on the interpretation of [42], almost the locations had questionable amounts of available phosphorus (Table 10). The analysis of variance showed that the amount of available phosphorus was significantly affected $(\mathrm{P} \leq 0.05)$ by conservation structures. The highest amount of phosphorus (5.77 ppm) was recorded in level bund which is significantly different from level fanya juu and control plots, followed by level fanya juu (5.18 ppm) which also is significantly different from the control plot (Table 10). The higher amount of phosphorus on level bund and level fanya juu than the control plot was due to higher organic carbon and organic matter values on level bund and level fanya juu (Table 6). Organic matter has two types of indirect influence on phosphorus availability. Iron and aluminum ions can be complexes and tied by organic matter. Complexion leaves iron and aluminum in a solution to precipitate insoluble phosphorous compounds [22].

Phosphorus showed no significant difference among all seven locations (Table 11), and this was probably because of slope similarity among locations. The lowest phosphorus value in the control plot is due to uncontrolled erosion, which washed away the nutrients, as well as crop removal of nutrients. The amount of loss varies for different elements. Phosphorous is mainly lost along with colloidal particles. Nitrogen in the nitrate form is soluble and so can be lost in solution in the runoff without any physical soil movement occurring [43].

\section{Changes in Soil Characteristics within the Inter-Structural Spaces of the Soil}

The area was studied to compare the variability in soil properties within the interstructural space using the mean values of selected soil properties in plots treated with conservation structures. Except for bulk density and total porosity, which differ significantly with location, there was a significant difference (P0.05) due to conservation measures and among the interstructural positions in soil physicochemical properties.

In terms of clay, silt, and sand content, there was a significant difference (P0.05) between the lower, upper, and middle positions (Table 12). The lowest values of clay (18.1) and silt (36.05) content were observed on the upper position whereas the highest values were observed on the lower position. One possible explanation is that erosion removed more top soil from the upper position and deposited it to the lower position between the two conservation structures. [44] Reported that the increase in clay content caused by erosion in the upper segment of a slope between bunds. The nutrient content and soil physical characteristics also showed a considerable difference because of erosion.

Table 12. Means of physicochemical properties in interstructural space of the soil.

\begin{tabular}{ccccc}
\hline \multirow{2}{*}{ Soil properties } & \multicolumn{4}{c}{ Positions on the conservation structures } \\
\cline { 2 - 5 } & Upper & Middle & Lower & LSD (0.05) \\
\hline TN (\%) & $0.179 \mathrm{~b}$ & $0.18 \mathrm{~b}$ & $0.19 \mathrm{a}$ & 0.01 \\
OC (\%) & $1.65 \mathrm{~b}$ & $1.824 \mathrm{~b}$ & $2.027 \mathrm{a}$ & 0.25 \\
OM (\%) & $3.14 \mathrm{c}$ & $3.36 \mathrm{~b}$ & $3.75 \mathrm{a}$ & 0.22 \\
Av.P (\%) & $4.82 \mathrm{~b}$ & $4.69 \mathrm{~b}$ & $5.4 \mathrm{a}$ & 0.46 \\
AV.K (mg/kg) & $13.44 \mathrm{~b}$ & $13.28 \mathrm{~b}$ & $15.47 \mathrm{a}$ & 0.77 \\
CEC (meq/100g) & $23.45 \mathrm{~b}$ & $23.13 \mathrm{~b}$ & $27.64 \mathrm{a}$ & 1.51 \\
AWHC (\%) & $15.11 \mathrm{~b}$ & $15.29 \mathrm{~b}$ & $17.46 \mathrm{a}$ & 1.34 \\
Porosity (\%) & $46.29 \mathrm{~b}$ & $46.61 \mathrm{~b}$ & $47.23 \mathrm{a}$ & 0.38 \\
Bulk density & $1.39 \mathrm{a}$ & $1.38 \mathrm{~b}$ & $1.38 \mathrm{~b}$ & 0.07 \\
(gm/cm $\left.{ }^{3}\right)$ & & & $6.28 \mathrm{a}$ & 0.14 \\
PH & $6.01 \mathrm{~b}$ & $6.11 \mathrm{~b}$ & $21.67 \mathrm{a}$ & 1.81 \\
Clay (\%) & $18.1 \mathrm{c}$ & $19.67 \mathrm{~b}$ & $44.29 \mathrm{a}$ & 2.62 \\
Silt (\%) & $36.05 \mathrm{c}$ & $38.86 \mathrm{~b}$ & $33.47 \mathrm{c}$ & 2.83 \\
Sand (\%) & $45.86 \mathrm{a}$ & $41.95 \mathrm{~b}$ & & \\
\hline
\end{tabular}


N.B. Means with the same letter in the column are not significantly different. (Source: analysis results).

Total nitrogen, organic carbon, organic matter, available phosphorous, available potassium, cation exchange capacity, and $\mathrm{PH}$ were the highest in the lower position (Table 12). According to farmer's and own field observation, lower crop yield was observed in the upper position. The basic reason for this is an increasing spatial variability of soil fertility and their translocation and deposition in the lower position. [45] Moreover found that during the erosion process that forms the terraces, the top soil below the structure is gradually moved down the slope and accumulates above the next soil and water conservation structures. Loss of organic matter not only resulted in reduced water holding capacity and degraded soil aggregation but also the loss of nutrients; decrease in soil porosity and increase in bulk density.

Consequently, the finer particles are moved to the lower depth or moved to other areas through erosion and thus leaving the coarser particles at the site [46] and [47] in a soil conservation research station observed soil and fertility redistribution along the transect in six years old well-established terraces in the conservation treated catchments. He reported that the soil immediately above the conservation structure had more available phosphorous, total nitrogen, and organic matter but less exchangeable potassium and clay content than the soil upslope. However, in our findings clay and potassium also have high content in the lower position (Table 12). Soil and water conservation structures and buffer zones can significantly reduce erosion and sediment transport caused by rainfall and surface runoff. These structures capture surface runoff or slow down their movement by increasing infiltration. Hence, untreated farm lands lose their all amount of nutrients if five tons of topsoil is removed but actually it is 7 tons. Erosion is the main cause of fertility and productivity loss in the study area. Erosion removes the most productive topsoil and the most selective nutrient rich finer particles.

4.Conclusion and Recommendations

\section{Conclusion}

Soil is a critical natural resource in crop production. It is critical to ensure good soil management to keep this resource available for current and future generations. The soil and water conservation structures (level bund and level fanya juu) studied in Lemmo District influenced the soil Physicochemical properties significantly $(\mathrm{P} \leq 0.05)$. Silt, clay, and sand were significantly affected by position and location and they are affected significantly by soil conservation structures $(\mathrm{P} \leq 0.05)$. No significant differences were observed on clay, silt, and sand content between level bund and level fanya-juu. Higher amount of clay content 20.333 and $21.429 \%$ was observed at level fanya ju and level bund plots, respectively. Highest silt (43.095\%) was observed on the level bund while the highest sand was observed on the control plot.

There was no significant difference between level bund and level fanya juu on the content of bulk density. Although non-significant higher bulk density $\left(1.399 \mathrm{gm} / \mathrm{cm}^{3}\right)$ was observed on the control plot than on level bund $\left(1.381 \mathrm{gm} / \mathrm{cm}^{3}\right)$ and level fanya juu (1.383 $\mathrm{gm} / \mathrm{cm}^{3}$ ) plots. No significant difference was observed between level bund and level fanya juu. Level bund has the highest average $(47.565 \%)$ pore volume whereas the lowest $(45.51 \%)$ was observed in the control plot. Soil and water conservation structures significantly affected available potassium, total nitrogen, organic matter content, phosphorous, organic carbon, soil $\mathrm{pH}$, and cation exchange capacity. No significant difference was observed on organic matter and organic carbon content, whereas there was a significant difference between the treated plots and the untreated plots.

The control plot had the lowest $\mathrm{pH}$ of $5.86 \%$. The mean organic matter percentages for level bund, level fanya juu, and control plot were 3.621 percent, 3.663 percent, and 2.973 percent, respectively. These values showed an increment of $23.21 \%$ and $21.76 \%$ over the control plot. No significant difference in organic matter content was observed between level bund and level fanya juu, whereas there was a significant difference between the 
control plot and treated plots. Location and position affected significantly porosity, nitrogen, phosphorus, potassium, organic matter, organic carbon, cation exchange capacity, and $\mathrm{pH}$ between inter-structural spaces of the bunds because there is a slope difference between interstructural spaces that is between the upper, middle and lower position. A prolonged dry season, high intensity rains, overgrazing, and poor farming practices are some of the contributing factors to the soil degradation in the area. Continuous and successful food crop production in the area, therefore, requires good cultural practices to minimize soil degradation.

\section{Recommendations}

soil and water conservation measures should have to be exercised on cultivated land where there is an erosion problem. Raising yield of agricultural production and improving the quantity of products will increasingly difficult without a steady use of soil and water conservation technologies. Hence, the government should encourage the respective offices to extend these technologies to be used by all farmers of the area to achieve the intended goals of agriculture. Farmers training centers should be used in greater extent for the dissemination of conservation information through demonstration. The role of soil and water conservation should be clarified, firmly established as common goals among the stakeholders, the approach should be holistic. Obstacles to conservation should be identified at the local level and dealt with as part of the program implementation process.

Hence, in the future we should have to give special attention to the construction of soil and water conservation by the farmers equally or more than the attention given to crop production. Because only production will never bring sustainability of the system without the continuous follow-up and maintenance of soil and water conservation structures by the farmers. If the level of awareness is high regarding the importance of soil and water conservation structures, there will be little need for intensified technical assistance, implementation of other programmes and strategies.

ACKNOWLEDGEMENTS: The authors would like to express their deepest thanks and gratitude to Wachemo University for the grant of field survey expenses and to all those participated in one way or another for the accomplishment of this study.

\section{REFERENCES}

1. [1] Bogale, M., Regassa, A. and Tilahun, A., 2020. Inter-structural Space Effect of Fanya juu and Soil Bund Soil and Water Conservation Structures on Selected Soil Properties: In the Case of Habru District, North Ethiopia.

2. [2] Gashaw, T., Tulu, T., Argaw, M. and Worqlul, A.W., 2019. Modeling the impacts of land use-land cover changes on soil erosion and sediment yield in the Andassa watershed, upper Blue Nile basin, Ethiopia. Environmental Earth Sciences, 78(24), p.679.

3. [3] Mekelle, E., 2015. Assessing Runoff and Soil Erosion By Water Using GIS And RS Techniques at Midmar Catchment, Northern Ethiopia BY: Tsegay Aregawi Gebremedhn (Doctoral dissertation, Mekelle University).

4. [4] Reij, C., Scoones, I. and Toulmin, C. eds., 2013. Sustaining the soil: indigenous soil and water conservation in Africa. Routledge.

5. [5] Engdayehu, G., Fisseha, G., Mekonnen, M. and Melesse, A.M., 2016. Evaluation of technical standards of physical soil and water conservation practices and their role in soil loss reduction: the case of Debre Mewi watershed, north-west Ethiopia. In Landscape dynamics, soils and hydrological processes in varied climates (pp. 789-818). Springer, Cham.

6. [6] Amdemariam, T., Selassie, Y.G., Haile, M. and Yamoh, C., 2011. Effect of soil and water conservation measures on selected soil physical and chemical properties and barley (Hordeum spp.) yield. Journal of Environmental Science and Engineering, 5(11).

7. [7] Melaku, N.D., Renschler, C.S., Flagler, J., Bayu, W. and Klik, A., 2018. Integrated impact assessment of soil and water conservation structures on runoff and sediment yield through measurements and modeling in the Northern Ethiopian highlands. Catena, 169, pp.140-150.

8. [8] Biratu, A.A. and Asmamaw, D.K., 2016. Farmers' perception of soil erosion and participation in soil and water conservation activities in the Gusha Temela watershed, Arsi, Ethiopia. International Journal of River Basin Management, 14(3), pp.329-336.

9. [9] Mekuria, W., 2013. Conversion of communal grazing lands into exclosures restored soil properties in the semi-arid lowlands of Northern Ethiopia. Arid Land Research and Management, 27(2), pp.153-166.DAaNRD (Department of Agricultural and Natural Resources Development) 2017. Five Years Development Report.

10. [10] DAaNRD (Department of Agricultural and Natural Resources Development) 2017. Five Years Development Report 
11. [11] Ilany, T., Ashton, M.S., Montagnini, F. and Martinez, C., 2010. Using agroforestry to improve soil fertility: effects of intercropping on Ilex paraguariensis (yerba mate) plantations with Araucaria angustifolia. Agroforestry systems, 80(3), pp.399-409.

12. [12] Khater, I.M.M., 2015. COMPARITIVE EFFECT OF SOME PLANTER FURROW OPENERS AND SEED COVERING DEVICES ON SOME SOIL PROPERTIES AND CROPS PRODUCTIVITY. Misr Journal of Agricultural Engineering, 32(4), pp.14691484 .

13. [13] Singh, V.K., Dwivedi, B.S., Singh, S.K., Majumdar, K., Jat, M.L., Mishra, R.P. and Rani, M., 2016. Soil physical properties, yield trends and economics after five years of conservation agriculture based rice-maize system in north-western India. Soil and Tillage Research, 155, pp.133-148.

14. [14] Ruiz-Colmenero, M., Bienes, R. and Marques, M.J., 2011. Soil and water conservation dilemmas associated with the use of green cover in steep vineyards. Soil and Tillage Research, 117, pp.211-223.

15. [15] Benavidez, R., Jackson, B., Maxwell, D. and Norton, K., 2018. A review of the (Revised) Universal Soil Loss Equation ((R) USLE): with a view to increasing its global applicability and improving soil loss estimates. Hydrol. Earth Syst. Sci, 22(11), pp.6059-6086.

16. [16] Fernández, C., Vega, J.A. and Vieira, D.C.S., 2010. Assessing soil erosion after fire and rehabilitation treatments in NW Spain: performance of RUSLE and revised Morgan-Morgan-Finney models. Land degradation E development, 21(1), pp.58-67.

17. [17] Sung, C.T.B., Joo, G.K., Chien, L.C. and Seng, S.T., 2011. Short-term changes in the soil physical and chemical properties due to different soil and water conservation practices in a sloping land oil palm estate. Pertanika J. Trop. Agric. Sci, 34(1), pp.4162 .

18. [18] Mu, H., Fu, S., Liu, B., Yu, B. and Wang, A., 2018. Influence of soil and water conservation measures on soil fertility in the Beijing mountain area. Environmental monitoring and assessment, 190(9), p.504.

19. [19] Guadie, M., Molla, E., Mekonnen, M. and Cerdà, A., 2020. Effects of Soil Bund and Stone-Faced Soil Bund on Soil Physicochemical Properties and Crop Yield Under Rain-Fed Conditions of Northwest Ethiopia. Land, 9(1), p.13.

20. [20] Erkossa, T., Williams, T.O. and Laekemariam, F., 2018. Integrated soil, water and agronomic management effects on crop productivity and selected soil properties in Western Ethiopia. International Soil and Water Conservation Research, 6(4), pp.305-316.

21. [21] Närhi, P., Middleton, M., Hyvönen, E., Piekkari, M. and Sutinen, R., 2010. Central boreal mire plant communities along soil nutrient potential and water content gradients. Plant and soil, 331(1-2), pp.257-264.

22. [22] Salem, H.M., Valero, C., Muñoz, M.Á., Rodríguez, M.G. and Silva, L.L., 2015. Short-term effects of four tillage practices on soil physical properties, soil water potential, and maize yield. Geoderma, 237, pp.60-70.

23. [23] Kumawat, A., Yadav, D., Samadharmam, K. and Rashmi, I., 2020. Soil and Water Conservation Measures for Agricultural Sustainability. In Soil Moisture Importance. IntechOpen.

24. [24] Belayneh, M., Yirgu, T. and Tsegaye, D., 2019. Effects of soil and water conservation practices on soil physicochemical properties in Gumara watershed, Upper Blue Nile Basin, Ethiopia. Ecological Processes, 8(1), p.36.

25. [25] Gonzalez, J.M., 2018. Runoff and losses of nutrients and herbicides under long-term conservation practices (no-till and crop rotation) in the US Midwest: A variable intensity simulated rainfall approach. International Soil and Water Conservation Research, 6(4), pp.265-274.

26. [26] Lilburne, L., Eger, A., Mudge, P., Ausseil, A.G., Stevenson, B., Herzig, A. and Beare, M., 2020. The Land Resource Circle: Supporting land-use decision making with an ecosystem-service-based framework of soil functions. Geoderma, 363, p.114134.

27. [27] Lugo López, M.A., Abruña, F. and Pérez Escolar, R., 2010. The role of crop and industrial residues on erosion control, properties and productivity of some major soils of Puerto Rico.

28. [28] Bennett, L.T., Mele, P.M., Annett, S. and Kasel, S., 2010. Examining links between soil management, soil health, and public benefits in agricultural landscapes: an Australian perspective. Agriculture, Ecosystems E Environment, 139(1-2), pp.1-12.

29. [29] Barnes, R.T., Gallagher, M.E., Masiello, C.A., Liu, Z. and Dugan, B., 2014. Biochar-induced changes in soil hydraulic conductivity and dissolved nutrient fluxes constrained by laboratory experiments. PloS one, 9(9), p.e108340.

30. [30] Nocco, M.A., Ruark, M.D. and Kucharik, C.J., 2019. Apparent electrical conductivity predicts physical properties of coarse soils. Geoderma, 335, pp.1-11.

31. [31] Sadeghi, M., Jones, S.B. and Philpot, W.D., 2015. A linear physically-based model for remote sensing of soil moisture using short wave infrared bands. Remote Sensing of Environment, 164, pp.66-76.

32. [32] Batjes, N.H., 2014. Projected changes in soil organic carbon stocks upon adoption of recommended soil and water conservation practices in the Upper Tana River catchment, Kenya. Land Degradation \& Development, 25(3), pp.278-287.

33. [33] Adimassu, Z., Langan, S., Johnston, R., Mekuria, W. and Amede, T., 2017. Impacts of soil and water conservation practices on crop yield, run-off, soil loss and nutrient loss in Ethiopia: review and synthesis. Environmental management, 59(1), pp.87-101.

34. [34] Li, J., Wu, X., Gebremikael, M.T., Wu, H., Cai, D., Wang, B., Li, B., Zhang, J., Li, Y. and Xi, J., 2018. Response of soil organic carbon fractions, microbial community composition and carbon mineralization to high-input fertilizer practices under an intensive agricultural system. PLoS One, 13(4), p.e0195144.

35. [35] Ademe, Y., Kebede, T., Mullatu, A. and Shafi, T., 2017. Evaluation of the effectiveness of soil and water conservation practices on improving selected soil properties in Wonago district, Southern Ethiopia. Journal of Soil Science and Environmental Management, 8(3), pp.70-79.

36. [36] Demelash, M. and Stahr, K., 2010. Assessment of integrated soil and water conservation measures on key soil properties in South Gonder, North-Western Highlands of Ethiopia. Journal of Soil Science and Environmental Management, 1(7), pp.164-176.

37. [37] Ziadat, F.M. and Taimeh, A.Y., 2013. Effect of rainfall intensity, slope, land use and antecedent soil moisture on soil erosion in an arid environment. Land Degradation E Development, 24(6), pp.582-590. 
38. [38] Hayes, M.H. and Swift, R.S., 2020. Vindication of humic substances as a key component of organic matter in soil and water. Advances in Agronomy. Sparks, DL (ed), pp.1-40.

39. [39] Woodard, J.D., 2016. Integrating high resolution soil data into federal crop insurance policy: Implications for policy and conservation. Environmental Science \& Policy, 66, pp.93-100.

40. [40] Mesfin, S., Taye, G. and Hailemariam, M., 2018. Effects of integrated soil and water conservation measures on soil aggregate stability, soil organic matter and soil organic carbon stock of smallholder farmlands in semi-arid Northern Ethiopia. Carbon Management, 9(2), pp.155-164.

41. [41] Behera, S.K., Mathur, R.K., Shukla, A.K., Suresh, K. and Prakash, C., 2018. Spatial variability of soil properties and delineation of soil management zones of oil palm plantations grown in a hot and humid tropical region of southern India. Catena, 165, pp.251-259.

42. [42] Lehman, R.M., Acosta-Martinez, V., Buyer, J.S., Cambardella, C.A., Collins, H.P., Ducey, T.F., Halvorson, J.J., Jin, V.L., Johnson, J.M., Kremer, R.J. and Lundgren, J.G., 2015. Soil biology for resilient, healthy soil. Journal of Soil and Water Conservation, 70(1), pp.12A-18A.

43. [43] Hudson, N., 2015. Soil conservation: fully revised and updated. Soil conservation: fully revised and updated., (Ed. 3).

44. [44] Shiene, S.D., 2012. Effectiveness of soil and water conservation measures for land restoration in the Wello area, northern Ethiopian highlands (Doctoral dissertation, Universitäts-und Landesbibliothek Bonn).

45. [45] Missong, A., Bol, R., Nischwitz, V., Krüger, J., Lang, F., Siemens, J. and Klumpp, E., 2018. Phosphorus in water dispersiblecolloids of forest soil profiles. Plant and soil, 427(1-2), pp.71-86.

46. [46] Bonilla, C.A. and Johnson, O.I., 2012. Soil erodibility mapping and its correlation with soil properties in Central Chile. Geoderma, 189, pp.116-123.

47. [47] Damene, S., Tamene, L. and Vlek, P.L., 2012. Performance of farmland terraces in maintaining soil fertility: a case of Lake Maybar watershed in Wello, Northern Highlands of Ethiopia. Journal of Life Sciences, 6(11), p.1251. 